\title{
ARCYBISKUP MARIAN GOŁĘBIEWSKI JAKO TEOLOG I PASTERZ
}

\section{WSTĘP}

Przyjął się zwyczaj w świecie nauki i kultury, a także w życiu Kościoła, pisania Ksiąg Pamiątkowych, dedykowanych znaczącym osobom, z okazji przeżywanych przez nich jubileuszy, czy też łączących się z przechodzeniem na emeryturę. Do grona autorów przygotowywanego dzieła zapraszani są wtedy koledzy, przyjaciele, uczniowie, wychowankowie. Jest mi niezwykle miło, że zostałem zaproszony do napisania tekstu, który znajdzie się w tomie „Teologia i Człowiek”, dedykowanym ks. prof. dr. hab. Zdzisławowi Pawlakowi, pracownikowi naukowemu Wydziału Teologicznego Uniwersytetu Mikołaja Kopernika w Toruniu, memu serdecznemu Koledze i Przyjacielowi z lat wspólnych studiów na Wydziale Filozofii Chrześcijańskiej Katolickiego Uniwersytetu Lubelskiego. Mamy

* Bp. Ignacy Dec - biskup świdnicki, prof. dr hab., kierownik Katedry Antropologii i Etyki w Instytucie Filozofii Papieskiego Wydziału Teologicznego we Wrocławiu, w latach 1988 - 1995 rektor Metropolitalnego Wyższego Seminarium Duchownego we Wrocławiu, w latach 1992 - 2004 rektor Papieskiego Wydziału Teologicznego. Promotor sześciu doktoratów „honoris causa” (m.in. kard. J. Ratzingera) i osiemnastu zwyczajnych. Autor wielu publikacji naukowych i duszpasterskich 
wspólnych mistrzów naszej edukacji filozoficznej. W trakcie minionych lat spotykaliśmy się od czasu do czasu na różnych sympozjach, sesjach i spotkaniach naukowych. Ks. Profesor był kilkakrotnie zapraszany do Wrocławia jako recenzent rozpraw doktorskich. Dlatego też chętnie włączam się do świętowani 70. rocznicy urodzin Księdza Profesora przez przygotowanie i dedykację poniższego tekstu.

W przedłożeniu niniejszym pragnę zaprezentować jednego z czołowych hierarchów dzisiejszego Kościoła w Polsce, wywodzącego się z diecezji włocławskiej, którym jest ks. arcybiskup Marian Gołębiewski, metropolita wrocławski. Na zawartość tekstu złożą się: krótki biogram Księdza Arcybiskupa, jego działalność naukowa i duszpasterska. Tłem do prezentacji sylwetki Księdza Arcybiskupa będzie przypomnienie ważnego dzieła ks. prof. Zdzisława Pawlaka, poświęconego wielkim sylwetkom Kościoła Włocławskiego poprzedniego stulecia.

\section{NAJNOWSZE TRADYCJE FILOZOFICZNO-TEOLOGICZNE ŚRODOWISKA WŁOCŁAWSKIEGO}

W roku 2001 ks. Zdzisław Pawlak, wychowanek Lubelskiej Szkoły Filozofii Klasycznej, opublikował we Włocławku książkę pt. Neoscholastyka i formy jej kontynuacji. Studium analityczno-krytyczne twórczości filozofów włoctawskich XX wieku (ss. 326). W książce zaprezentował twórczość filozofów włocławskich XX wieku. Chciał ich ukazać jako kontynuatorów różnych odłamów neoscholastyki europejskiej. Spośród wymienionych ośmiu włocławskich filozofów autor w pracy ukazał myśl filozoficzną czterech księży, którzy posiadają największy dorobek pisarski w dziedzinie filozofii. Są to: ks. Idzi Radziszewski, profesor i rektor trzech uczelni (Wyższego Seminarium Duchownego we Włocławku, Akademii Duchownej w Petersburgu, założyciel i pierwszy rektor Katolickiego Uniwersytetu w Lublinie), ks. Józef Iwanicki, profesor i rektor dwóch uczelni (Katolickiego Uniwersytetu Lubelskiego i Akademii Teologii Katolickiej w Warszawie), ks. Stanisław Mazierski, profesor Katolickiego Uniwersytetu Lubelskiego i jeden z głównych współtwórców sekcji filozofii przyrody na tejże uczelni i ks. Adam Jankowski, wykładowca przedmiotów filozoficznych w Wyższym Seminarium Duchownym we Włocławku.

Jak wykazał autor, wymienieni myśliciele reprezentowali i kontynuowali trzy odmiany filozofii neoscholastycznej i wnieśli znaczący wkład do polskiej filozofii. Ks. Idzi Radziszewski i ks. Adam Jankowski 
kontynuowali w jakimś stopniu neoscholastykę Szkoły Lowańskiej, pierwszy głównie przez publikacje, drugi - bardziej przez swoją działalność naukowo-dydaktyczną. Warto przypomnieć, że niniejsza wersja neoscholastyki łączyła filozofię tomistyczną z osiągnięciami nauk szczegółowych, zwłaszcza przyrodniczych.

Ksiądz Józef Iwanicki był kontynuatorem innej wersji scholastyki, mianowicie wersji logicznej. Dokładniej mówiąc w odmianie tej łączono scholastykę z osiągnięciami współczesnej logiki. Niniejsza odmiana neoscholastyki przywędrowała do Polski drogą okrężną, najpierw przez ośrodek wiedeński, a potem poprzez szkołę lwowsko-warszawską. W wersji tej usiłowano uściślać filozofię scholastyczną za pomocą logiki współczesnej. Miało to duże znaczenie dla rozwoju neoscholastyki. Przybliżało tę filozofię do wiedzy naukowej i wyostrzało przez to samo świadomość metodologiczną.

Wreszcie, trzeci myśliciel, ks. Stanisław Mazierski, reprezentował zasadniczo nurt filozofii neoscholastycznej, wywodzący się z lowańskiej filozofii przyrody. Jednakże konfrontował lowańskie rozstrzygnięcia ze stanowiskiem Lubelskiej Szkoły Filozofii Klasycznej, poddając je rygorom metodologicznym i teoriopoznawczym.

Jeśli to tych znakomitych myślicieli, przedstawionych bardzo kompetentnie przez ks. prof. Zdzisława Pawlaka, dodamy postać ks. kard. Stefana Wyszyńskiego, który pierwsze lata kapłańskiego życia wypełnił posługą w diecezji włocławskiej, to trzeba jednoznacznie powiedzieć, iż włocławskie środowisko teologiczne było kolebką wielkich ludzi, którzy w różnych miejscach i w różny sposób rozsławili polską myśl teologiczną i filozoficzno-społeczną.

Do tych ludzi należy dziś dołączyć ks. arcybiskupa Mariana Gołębiewskiego, syna ziemi włocławskiej.

\section{ZARYS BIOGRAMU KSIĘDZA ARCYBISKUPA MARIANA GOŁĘBIEWSKIEGO}

Ksiądz arcybiskup Marian Gołębiewski urodził się 22 września 1937 roku w Trzebuchowie w pobliżu Koła ${ }^{\square}$. W rodzinnej miejscowości spędził swoje dzieciństwo i wczesną młodość. Początkowe lata życia naznaczyła swoją okropnością druga wojna światowa. Po jej zakończeniu chłopiec Marian mógł rozpocząć edukację w szkole podstawowej w Dębach Szlacheckich (1945-1952), a następnie w Niższym Seminarium 
Duchownym im. Jana Długosza we Włocławku (1952-1956). Gdy odkrył w sobie powołanie kapłańskie, wstąpił do Wyższego Seminarium Duchownego we Włocławku, gdzie odbył sześcioletnie studia filozoficzno-teologiczne oraz formację ascetyczną i duszpasterską (1956-1962). Czas studiów seminaryjnych, jak również okres wcześniejszej edukacji, był bardzo trudny ze względu na ówczesną sytuację gospodarczą i społeczno-polityczną w naszej Ojczyźnie. W kraju panowała nie tylko bieda spowodowana zniszczeniem wojennym, ale mocno dawał się we znaki stalinowski reżim komunistyczny. Do minimum ograniczano działalność Kościoła katolickiego, rozprawiano się bezpardonowo z opozycją polityczną, zgrupowaną w obozie patriotycznym. Represje reżimu dosięgły także Wyższego Seminarium Duchownego we Włocławku.

Kleryk Marian Gołębiewski szczęśliwie ukończył formację seminaryjną i 24 czerwca 1962 roku, został wyświęcony na kapłana. Święcenia przyjął w katedrze włocławskiej z rąk biskupa Antoniego Pawłowskiego. Z Wieczernika Kościoła włocławskiego wyruszył na żniwo Pańskie. Jako wikariusz posługiwał kolejno w dwóch parafiach: Ślesin (1962-1964) oraz Zduńska Wola (1964-1966). Cztery lata pracy parafialnej stworzyły dobrą sposobność do zapoznania się z problemami rodziny i parafii, co okazało się bardzo przydatne dla późniejszej posługi kapłańskiej.

Po latach wikariatu rozpoczęła się w życiu młodego księdza Mariana niezwykła przygoda studiów specjalistycznych z zakresu Pisma Świętego. Najpierw był to Wydział Teologii Katolickiego Uniwersytetu Lubelskiego (1966-1969) i spotkanie z teologią, zwłaszcza biblistyką, naszego kraju. Trzyletnie studia specjalistyczne na KUL-u zostały uwieńczone magisterium i licencjatem rzymskim $\mathrm{z}$ teologii, uzyskanym pod kierunkiem znanego i cenionego biblisty, ks. prof. dr hab. Stanisława Łacha. W roku 1969 życiowe drogi poprowadziły ks. Gołębiewskiego z Lublina w szeroki świat, do stolicy chrześcijaństwa, do Rzymu. Tu - w Papieskim Instytucie Biblijnym - nastąpiło spotkanie z teologią i biblistyką Kościoła powszechnego. Po dwóch latach trudnych, żmudnych studiów ks. Marian Gołębiewski uzyskał licencjat nauk biblijnych (1971) i po niezbędnych przygotowaniach przystąpił do pisania rozprawy doktorskiej. W 1973 roku na łamach włocławskiego dwumiesięcznika „Ateneum Kapłańskie” ukazała się pierwsza publikacja ks. Gołębiewskiego, poświęcona obchodzonym wówczas we Włoszech uroczystościom kopernikańskim. Rok później, w tymże czasopiśmie, zapoznał czytelników polskich z najnowszymi publikacjami o tematyce biblijnej, szczególnie dotyczącymi Księgi Izajasza. W 1975 roku doktorant nauk biblijnych wziął udział w podróży 
studyjnej do Ziemi Świętej prowadzonej przez profesora Papieskiego Instytutu Biblijnego Roberta Northa SJ. W 1976 roku przyszedł czas na uwieńczenie rzymskich studiów doktoratem nauk biblijnych na podstawie pracy Analyse litteraire et theologique d'Isaie 54-55: Une alliance eternelle avec la nouvelle Jerusalem, napisanej pod kierunkiem prof. R.P. Merendino, której fragmenty zostały wydane drukiem. Dyplom doktorski został nostryfikowany 29 kwietnia 1977 roku przez Radę Wydziału Teologii Katolickiego Uniwersytetu Lubelskiego. Trzeba zaznaczyć, że doktorat nauk biblijnych był w tamtym czasie bardzo wielkim osiągnięciem, gdyż jeszcze $\mathrm{w}$ połowie lat sześćdziesiątych poprzedniego stulecia jedynym kapłanem posiadającym doktorat nauk biblijnych w Polsce był ks. Eugeniusz Dąbrowski.

\section{DZIAZALNOŚĆ NAUKOWO-DYDAKTYCZNA}

Po studiach rzymskich, ks. dr Marian Gołębiewski jesienią 1976 roku rozpoczął pracę dydaktyczną jako wykładowca Pisma Świętego Starego Testamentu oraz lektor języka greckiego, łacińskiego i angielskiego w Wyższym Seminarium Duchownym we Włocławku. Wkrótce na łamach "Ateneum Kapłańskiego" (1977) oraz kwartalnika teologów polskich "Collectanea Theologica" (1979) ukazały się jego pierwsze artykuły naukowe. W latach 1978-1986 był członkiem kolegium redakcyjnego „Ateneum Kapłańskiego", odpowiedzialnym za dział bibliograficzny i teologiczną adiustację nadsyłanych tekstów. Od 1978 do 1989 roku pełnił funkcję sędziego w Sądzie Biskupim we Włocławku. Władze kościelne bez trudności rozpoznały naukowe kompetencje i talent wychowawczy młodego rzymskiego doktora i wprowadziły go do grona wychowawców alumnów Wyższego Seminarium Duchownego we Włocławku. W latach 1981-1983 pełnił w nim funkcję prefekta studiów, a potem, aż do roku 1993, kierował Seminarium jako rektor, łącząc pracę naukową z pracą wychowawczą wśród kandydatów do kapłaństwa.

Od początku nauczania we Włocławskim Wyższym Seminarium Duchownym ks. dr Marian Gołębiewski prowadził seminarium naukowe z zakresu Starego Testamentu. Pod jego kierunkiem napisano i obroniono na Wydziale Teologii Katolickiego Uniwersytetu Lubelskiego, do którego było afiliowane włocławskie WSD, 30 prac magisterskich i dyplomowych. W 1980 roku podjął zajęcia zlecone z egzegezy Starego Testamentu na Wydziale Teologicznym Akademii Teologii Katolickiej w Warszawie, 
gdzie trzy lata później, w 1983 roku, został zaangażowany jako adiunkt. Jego zainteresowania naukowe skupiały się wokół problematyki starotestamentowych ksiąg prorockich, zwłaszcza Deutero-Izajasza.

Praca w warszawskim środowisku teologicznym zmobilizowała młodego Doktora do przygotowania rozprawy habilitacyjnej. Nie zaniedbując funkcji wychowawczych, ks. rektor Marian Gołębiewski przygotował rozprawę habilitacyjną pt. Hymny samopochwalne Jahwe u Deutero-Izajasza (40-48). Studium literacko-krytyczno-teologiczne. Na jej podstawie oraz na podstawie całego dorobku naukowego, 28 lutego 1994 roku na Wydziale Teologicznym Akademii Teologii Katolickiej odbyło się kolokwium habilitacyjne, po którym habilitant otrzymał stopień doktora habilitowanego teologii w zakresie biblistyki. Dnia 1 grudnia tegoż roku został powołany na kierownika Katedry Biblistyki Starego Testamentu, zastępując na tym stanowisku ks. biskupa prof. Henryka Muszyńskiego. Już w roku następnym, 1 czerwca 1995 roku ks. dr. hab. Marianowi Gołębiewskiemu powierzono pełnienie obowiązków kierownika Katedry Filologii Biblijnej. Niespełna trzy miesiące później, 21 września 1995 roku, otrzymał nominację na stanowisko profesora nadzwyczajnego.

W swojej działalności naukowo-badawczej ks. Marian Gołębiewski skupił się głównie wokół problematyki Deutero-Izajasza. Są to rozdziały środkowe Księgi Izajasza, od rozdziału 40. do 55., poprzedzone Proto-Izajaszem (rozdz. 1-39) i dopełnione Trito-Izajaszem (rozdz. 56-66). Badania nad Deutero-Izajaszem rozszerzyły się na całą działalność naukową ks. Gołębiewskiego, poczynając od rozprawy doktorskiej, pisanej w pierwszej połowie lat siedemdziesiątych, a kończąc na rozprawie habilitacyjnej, przedłożonej w 1994 roku.

Ksiądz prof. Lech Stachowiak w recenzji oceniającej dorobek naukowy i rozprawę habilitacyjną ks. dr Mariana Gołębiewskiego, w roku 1994, napisał:

Patrząc na analizę ks. dr. Gołębiewskiego z punktu widzenia biblijno-krytycznego, należy stwierdzić z uznaniem, iż wnosi ona istotny element postępu nie tylko w biblistyce polskiej ale i ogólnoeuropejskiej. Stanowi ona znaczny krok naprzód w dziedzinie zaawansowanych badań nad orędziem Deutero-Izajasza. [Nieco dalej dodał:] Należy z uznaniem stwierdzić, że ks. dr Gołębiewski reprezentuje w pełni współczesny nurt badań starotestamentalnych. Nie zaniedbuje dociekań formalno-krytycznych (po linii ostatniego dokumentu Papieskiej Komisji Biblijnej, L'interpretation de la Biblie dans l'Eglise, Città del Vaticano 1993, s. 28-34), gdzie wykazuje duże doświadczenie, ale też nie gubi się w spekulacjach 
strukturalistycznych [...], lecz opiera się jedynie na ogólnie utrwalonych zasadach. Godnym uwagi jest spory materiał porównawczy z kręgu paralelnych literatur starowschodnich, niewykorzystywanych jednak. Nie waha się autor stwierdzić formalnej zależności Deutero-Izajasza od nich przy jednoczesnym podkreśleniu oryginalnego ujęcia proroka.

O prof. Hugolin Lankammer, w recenzji dorobku naukowego do doktoratu honoris causa ks. Arcybiskupa, napisał:

Marian Gołębiewski ukazał właśnie różnorodne ujęcia literackie poszczególnych hymnów, które podobnie jak pieśń o Wielkości Boga wywołują podziw i bojaźń Bożą, nie lęk, gdyż Bóg zapowiada zbawienie [...]. Wnikając głębiej w rozprawę habilitacyjną Mariana Gołębiewskiego, nie tylko zauważa się ogromną wiedzę „warsztatową autora”, lecz także wyczytanie $\mathrm{z}$ tekstów natchnionych jej właściwej intencji i to na podstawie ścisłej dyskursywnej analizy, która doprowadza do rzeczowej teologicznej syntezy"1.

Z innych prac biblijnych autora, wysoko ocenionych przez fachowych biblistów, należy wymienić rozdział w pracy zbiorowej pt. Wstęp do Starego Testamentu, dotyczący Proroków Mniejszych. Autor wykazał tu umiejętność zwartego i jasnego przedstawienia dość trudnego i zróżnicowanego materiału obejmującego przesłanie tychże proroków. Tematycznie związany z głównym nurtem badań jest także artykuł pt. Idea stworzenia w Biblii Hebrajskiej umieszczony w ekumenicznej pracy zbiorowej Kościót a Żydzi i judaizm (Warszawa 1991, s. 53-71), gdzie obok fachowej znajomości teologicznej autor wykazał swe zainteresowanie dialogiem z Żydami.

W bibliografii naukowej ks. arcybiskupa Mariana Gołębiewskiego znajdujemy jeszcze sporo innych pozycji z zakresu szeroko rozumianej biblistyki, w tym - kilka w językach obcych. Dobra znajomość języków kongresowych pozwoliła ks. Arcybiskupowi czynnie uczestniczyć w różnych międzynarodowych debatach teologicznych.

Prezentację naukowych osiągnięć ks. Arcybiskupa można by podsumować następującymi słowami ks. prof. Lecha Stachowiaka z jego recenzji:

${ }^{1} \mathrm{H}$. Langkammer, Recenzja w sprawie wniosku o nadanie Arcybiskupowi prof. drowi hab. Marianowi Gołęiewskiemu tytutu doktora honoris causa Papieskiego Wydziatu Teologicznego we Wroctawiu, w: Arcybiskup Marian Gotębiewski doktor honoris causa Papieskiego Wydziatu Teologicznego we Wroctawiu, Wrocław 13 listopada 2008, s. 30. 
Oceniając syntetycznie działalność naukową i dorobek ks. dr Gołębiewskiego trudno go nie określić jako znaczny tak pod względem analityczno-naukowym jak i dydaktyczno-praktycznym. Zapewnił on sobie trwałą pozycję w badaniach nad Deuteroizajaszem, którym zajmuje się przez cały okres swej działalności. Prace jego nie mają jednak charakteru wycinkowego, ale zawsze traktuje je w kontekście całej teologii biblijnej Starego Testamentu. Nie obca mu jest żadna z dziedzin naukowej współczesnej biblistyki.

Omawiając działalność naukowo-dydaktyczną ks. Gołębiewskiego, należy też wspomnieć o jego pracach w różnych komisjach i gremiach kościelnych oraz naukowych. Jako rektor Wyższego Seminarium Duchownego we Włocławku był członkiem Rady Kapłańskiej i Kolegium Konsultorów diecezji włocławskiej, a także członkiem Komisji Episkopatu Polski ds. Seminariów. W tym okresie był również członkiem Komisji Presynodalnej ds. Wychowania Katolickiego. Prowadził również zajęcia w Instytucie Pastoralnym przy Wyższym Seminarium Duchownym oraz w Instytucie Wyższej Kultury Religijnej we Włocławku, a także - przez trzy lata - wykłady z Pisma Świętego w Wyższym Seminarium Duchownym Misjonarzy Ducha Świętego w Bydgoszczy.

Ksiądz rektor Marian Gołębiewski jako dobrze wykształcony biblista i znawca kultury żydowskiej przyczynił się znacząco do ożywienia dialogu chrześcijańsko i polsko-żydowskiego. Gdy w 1986 roku powstała Podkomisja Episkopatu Polski ds. Dialogu z Judaizmem, podniesiona półtora roku później do rangi Komisji, na której czele stanął bp Józef Henryk Muszyński - ówczesny biskup włocławski, ks. dr Marian Gołębiewski został włączony do tego gremium. W spotkaniach i dyskusjach był zawsze wyczulony na argumenty i odczucia strony żydowskiej, a zarazem bronił pozycji katolickich i polskich we wszystkich drażliwych sprawach. Brał też udział w różnych spotkaniach, także w organizowanych od 1989 roku w Warszawie corocznych sympozjach „Kościół a Żydzi i judaizm”. Pierwsze sympozjum z tego cyklu stanowiło bezpośrednie przygotowanie do seminarium naukowego dla księży profesorów z Polski, zorganizowanego w Spertus College of Judaica w Chicago. Ks. dr Marian Gołębiewski należał tam do grupy osób dobrze władających językiem angielskim i zaznajomionych z problematyką dialogu między religijnego.

Gdy w kwietniu 2004 roku otrzymał nominację na arcybiskupa metropolitę wrocławskiego i stał się tym samym Wielkim Kanclerzem Papieskiego Wydziału Teologicznego we Wrocławiu, ks. Arcybiskup zatroszczył się o odpowiednią formację ascetyczną kleryków ducho- 
wieństwa, a także o wysoki poziom ich formacji teologicznej. Jako wielki kanclerz otoczył swoją troską Papieski Wydział Teologiczny, mobilizując pracowników naukowo-dydaktycznych do szybkiego osiągania stopni i tytułów naukowych: doktora, doktora habilitowanego i tytułu profesora. Mimo że obowiązki Arcybiskupa nie sprzyjają osobistej systematycznej pracy naukowej, to jednak ks. arcybiskup Marian Gołębiewski znajduje czas na przewodniczenie posiedzeniom Rady Wydziału w Papieskim Wydziale Teologicznym we Wrocławiu. W miarę możliwości bierze udział w wybranych spotkaniach naukowych. Zabiega o odpowiedni poziom studiów teologicznych. $Z$ jego inspiracji i przy jego udziale organizowane są sympozja naukowe dla alumnów i studentów świeckich, w których biorą również udział osobistości świata kultury i nauki, społeczności akademickiej uczelni Dolnego Śląska.

\section{DZIAŁALNOŚĆ DUSZPASTERSKA}

Z chwilą, gdy ks. prof. Marian Gołębiewski został powołany do godności biskupiej, trzeba było nieco zrezygnować z pracy naukowej, by podjąć w szerszym zakresie działalność duszpasterską. Zaraz po odbyciu Ingresu do katedry koszalińskiej i przyjęciu święceń biskupich, ks. biskup koszalińsko-kołobrzeski musiał się zmierzyć z trudnymi problemami duszpasterskimi powierzonej mu diecezji. Objęcie posługi biskupiej w diecezji, położonej na tzw. Ziemiach Odzyskanych, zbiegło się w naszym kraju z czasem tzw. transformacji ustrojowej, która nastąpiła po tzw. „jesieni ludów” w 1989 roku. Za jej sprawą w Polsce stało się wiele dobrego. Z kraju zostały wyprowadzone obce wojska, które w większości stacjonowały na Ziemiach Zachodnich. Zlikwidowano cenzurę, przywrócono wolność słowa. Zaczęto przestawiać gospodarkę centralistyczną na wolnorynkową. W życiu społeczno-politycznym nastawiono się na budowę demokracji. Jednakże transformacja ustrojowa przyniosła także negatywne skutki, zwłaszcza na Ziemiach Zachodnich, które po wiekach powróciły do Macierzy. W rejonie Wałbrzycha i Nowej Rudy upadły kopalnie, na północy kraju upadły polskie stocznie, w wielu miejscowościach doprowadzono do upadku zakładów przemysłowych. Czasem nazywano to podstępnie procesem prywatyzacji, a było to równoznaczne z wysprzedażą - niekiedy za bezcen - majątku narodowego. W obce ręce przechodził powoli kapitał: kopalnie, huty, przedsiębiorstwa, banki, media. W rejonach wiejskich, w szczególności na Ziemiach Odzyskanych, 
przystąpiono do likwidacji, funkcjonujących tu od drugiej wojny światowej Państwowych Gospodarstw Rolnych, które w tym rejonie obejmowały ok. $80 \%$ ornej ziemi. Nie potrafiono uwłaszczyć byłych pracowników PGR. W środowiska wiejskie zawitało wielkie bezrobocie i bieda.

W taką właśnie sytuację, na Ziemie Zachodnie, w region Pomorza, wszedł w 1996 roku biskup Marian Gołębiewski. Trzeba było już na początku posługi zmierzyć się $\mathrm{z}$ wielką biedą duchową i materialną: bezrobociem, pijaństwem, konkubinatami, nieślubnymi dziećmi, opuszczoną młodzieżą. Nowy biskup dzielnie przystąpił do likwidacji skutków patologii reżimu komunistycznego. Rozwinął przede wszystkim działalność kościelnej Caritas. Otoczył opieką Dom Samotnej Matki, hospicja. Powołał do życia „Fundację Pomocy dla Kształcenia Młodzieży Wiejskiej", której zadaniem było niesienie pomocy zagubionej młodzieży, wywodzącej się niejednokrotnie z rozbitych małżeństw i rodzin patologicznych. Na konferencjach dziekańskich podczas wizytacji kanonicznych mobilizował duchowieństwo i wiernych do solidarnej miłości bliźniego, do niesienia pomocy biednym i zagubionym. Dużą troską otoczył także mienie materialne Kościoła. Doglądał osobiście remontów kościołów i plebanii. Popierał budowę nowych, koniecznych obiektów kościelnych. Młody biskup pisał rzeczowe Listy Pasterskie. Wygłaszał krótkie, dobrze przygotowane kazania.

Nowy biskup koszalińsko-kołobrzeski włączył się czynnie w problemy życia społecznego, społecznego i politycznego. W 62. rocznicę masowej wywózki na Syberię mówił w katedrze koszalińskiej: „Zadośćuczynienie dla ofiar prześladowanych, to sprawa sumienia i honoru współczesnych elit władz rosyjskich. Mam nadzieję, że władze rosyjskie sprostają moralnym wyzwaniom"2.

Równie klarownie wypowiadał się ks. Biskup o rzeczywistości Kościoła. Na rozpoczęcie Roku Jubileuszowego 2000 prosił o przebaczenie za dawne i obecne grzechy Kościoła, za wojny religijne, za dwie straszne wojny światowe i dwa totalitaryzmy, które zrodziły się w sercu chrześcijańskiej Europy, za holokaust i eksterminację milionów ludzi. Podczas jubileuszowej pielgrzymki księży, biskup koszalińsko-kołobrzeski przepraszał publicznie za nadmierne przywiązanie kapłanów do dóbr materialnych, zaszczytów, ludzkich względów, protekcji oraz niemądrych kompromisów społecznych i politycznych. Biskup wzywał swoich prezbiterów do pasterskiej gorliwości, stawiał im wysokie wymagania.

${ }^{2}$ Cyt. za: tamże; por. H. Langkammer, Recenzja, s. 25. 
Nie unikał też trudnych problemów życia kapłańskiego. Odważnie mówił o najczęstszych słabościach i grzechach prezbiterów. Nawoływał do wierności kapłańskim przyrzeczeniom ${ }^{\square}$.

Aktywna działalność biskupa koszalińsko-kołobrzeskiego nie uszła uwagi Ojca Świętego Jana Pawła II i nuncjusza apostolskiego w Polsce Józefa Kowalczyka. Gdy zakończyła się ponad dwudziestoośmioletnia posługa pasterska kard. Henryka Gulbinowicza w Archidiecezji Wrocławskiej, właśnie ten biskup biblista został wybrany na jego następcę na stolicę arcybiskupią we Wrocławiu. A dokonało się to 3 kwietnia 2004 roku.

Ingres Księdza Arcybiskupa do Katedry Wrocławskiej odbył się 24 kwietnia 2004 roku. Wzięło w nim udział ponad trzydziestu biskupów, na czele z ks. kard. Franciszkiem Macharskim i ks. arcybiskupem Józef Kowalczykiem, nuncjuszem apostolskim w Polsce.

Nowy Metropolita Wrocławski przejął dziedzictwo duszpasterskie ks. kard. Henryka Gulbinowicza. Od samego początku swego duszpasterzowania położył nacisk na formację kleryków i stałą formację prezbiterów w myśl zasady: przez dobrą formację kapłanów do dobrej formacji wiernych świeckich.

Jako pasterz Archidiecezji szczególną troską otoczył dzieło duszpasterstwa parafialnego i dzieło nowej ewangelizacji. Nowa ewangelizacja w wydaniu ks. Arcybiskupa ma nie tylko zwięzłą, komunikatywną formę, ale także zawiera bogatą, fundamentalną dla jakiegoś problemu, treść. Kerygmat biblijny aplikowany jest do konkretnych, dzisiejszych warunków codziennego życia, z krytyczną interpretacją i odważną oceną nadużyć w dziedzinie życia społeczno-politycznego.

Rozumienie nowej ewangelizacji przez ks. Arcybiskupa daje się odczytać z książki $W$ blaskach nowej ewangelizacji, wydanej z okazji 10-lecia jego sakry biskupiej. Lektura książki przekonuje nas, że ks. abp Marian Gołębiewski ma niezwykły dar ujmowania zagadnień w sposób jasny $\mathrm{i}$ istotny. $\mathrm{W}$ jego wywodach nie ma niepotrzebnych słów. Pomijane są sprawy marginalne, drugorzędne, a uwydatniane są rysy istotne dla rozważanych prawd i tematów. Teksty Autora wypełnione są nie tylko licznymi cytatami i wątkami biblijnymi, ale jest $\mathrm{w}$ nich obecna refleksja teologiczna i przede wszystkim odniesienie do życia, a więc jest ukazywany praktyczny, egzystencjalny wymiar rozważanych prawd. $Z$ tego też tytułu czytelnicy książki mogą znaleźć w kazaniach Księdza Arcybiskupa wiele światła i wskazówek dla chrześcijańskiego życia, a kapłani - dodatkowo - mogą otrzymać inspirację i wzorzec do przepowiadania słowa Bożego w ich posłudze pasterskiej. 
Doniosłym wkładem ks. arcybiskupa Mariana Gołębiewskiego w dziedzinie krzewienia myśli i kultury biblijnej jest "Dzieło Biblijne” w parafiach, a w kościołach Wrocławia, w cyklu comiesięcznych spotkań „Verbum cum musica”, wykłady profesorów, przybierające formę wydarzenia artystycznego, przy dźwiękach muzyki znanych twórców.

Dzieło to jeszcze bardziej dowartościował ks. Arcybiskup po XII Zwyczajnym Zgromadzeniu Synodu Biskupów, który obradował w Rzymie w październiku 2008 roku na temat: „Słowo Boże w życiu i misji Kościoła". Ks. Arcybiskup był zwyczajnym uczestnikiem tegoż Synodu, wybranym przez Konferencję Episkopatu Polski i zatwierdzonym przez Watykan.

Kreśląc sylwetkę arcybiskupa metropolity wrocławskiego, jako pasterza, nie sposób nie wspomnieć o jego trosce o budowę i remonty kościołów, plebanii i innych obiektów sakralnych. Ową troskę można scharakteryzować przez pryzmat prac remontowych prowadzonych na Ostrowie Tumskim we Wrocławiu. Zaraz po przyjściu do archidiecezji została poddana kapitalnemu remontowi rezydencja arcybiskupów wrocławskich. Następnie podjęto gruntowny remont głównego gmachu Papieskiego Wydziału Teologicznego. Nastąpiła tu nastąpiła modernizacja i komputeryzacja uczelnianej sieci informatycznej. Kolejnym obiektem poddanym remontowi był gmach Metropolitalnej Kurii Arcybiskupiej, a w ostatnim etapie gmach słynnej "Czwórki", w której kiedyś mieścił się kiedyś Centralny Ośrodek Duszpasterstwa Akademickiego we Wrocławiu. Trwają także nieustannie prace renowacyjne przy archikatedrze wrocławskiej. W wielu parafiach Archidiecezji budowane są nowe świątynie i kaplice. To wszystko świadczy o wielkiej pieczy pasterskiej i administracyjnej Wrocławskiego Metropolity.

Patrząc na całokształt działalności eklezjalnej ks. arcybiskupa Jubilata, należy zauważyć, że w Episkopacie Polskim ks. Arcybiskup postrzegany jest jako pasterz otwarty na świat, na problemy współczesności, jako człowiek dialogu i zdrowej ekumenii. Warto na koniec przypomnieć, że aktualnie ks. arcybiskup Marian Gołębiewski jest członkiem Papieskiej Rady Duszpasterstwa Migrantów i Podróżnych, członkiem Rady Stałej Konferencji Episkopatu Polski, przewodniczącym Rady ds. Apostolstwa Świeckich Konferencji Episkopatu Polski, przewodniczącym Sekcji Biblijnej Komisji Nauki Wiary przy Konferencji Episkopatu Polski, członkiem Komisji Nauki Wiary oraz członkiem Rady Naukowej Konferencji Episkopatu Polski.. 


\section{ZAKOŃCZENIE}

Niniejsza, szkicowa prezentacja działalności naukowej i duszpasterskiej ks. arcybiskupa Mariana Gołębiewskiego, metropolity wrocławskiego, pozwala nam na wyrażenie przekonania, że ks. Arcybiskup dołącza do świetlanych osób wywodzących się z Kościoła Włocławskiego. Jest szczególnym przykładem udanego łączenia katedry profesorskiej i katedry biskupiej, pracy naukowej z pracą duszpasterską. Należy przypuszczać, że posługę biskupią bardzo ułatwiły mu studia i działalność naukowo-dydaktyczna w dziedzinie nauk biblijnych. Lata posługi duszpasterskiej zarówno w diecezji koszalińsko-kołobrzeskiej, jak i w archidiecezji wrocławskiej pokazują, że Ksiądz Arcybiskup znakomicie przeszczepił swoją wiedzę biblijną na grunt duszpasterski, w szczególności w dziedzinę głoszenia słowa Bożego. Należy życzyć, by sławetna diecezja włocławska nadal wydawała wspaniałych ludzi nauki i duszpasterzy, by kapłani z niej się wywodzący byli ozdobą Kościoła w naszej Ojczyźnie. Niech wśród nich znajdzie się też ks. prof. dr hab. Zdzisław Pawlak.

\section{MONS. MARIAN GOŁĘBIEWSKI, TEOLOGO E PASTORE, FIGLIO DELLA TERRA DI WŁOCŁAWEK}

\section{RIASSUNTO}

L'autore del presente studio presenta uno dei maggiori gerarchi della Chiesa in Polonia dell'epoca moderna, l'arcivescovo e metropolita di Wrocław, Mons. Marian Gołębiewski, figlio della diocesi di Włocławek.

L'articolo comincia con una breve biografia di Mons. M. Gołębiewski (con l'accento sulla sua profonda educazione nel campo delle scienze bibliche), segue dunque una sintetica descrizione della sua attività scientifico-didattica (con una speciale messa in rilievo della sua importante posizione tra i biblisti polacchi, nonché dei meriti del Prof. Gołębiewski nel campo dello studio su Deutero-Isaia). L'articolo continua con una breve descrizione della sua attività pastorale, specialmente nel campo della "nuova evangelizzazione", fondata sull'approfondimento della vicinanza alla parola di Dio dei fedeli nelle diocesi a lui affidate.

L'autore, infine, intraprende una sintesi del ruolo di Mons. Gołębiewski nell'attuale situazione pastorale e scientifico-sociale della Chiesa in Polonia. Il presente schizzo letterario sulla persona dell'Arcivescovo di Wrocław, conduce il lettore ad una importante considerazione: Mons. Gołębiewski, mostrando un esempio di una ben riuscita unione della cattedra universitaria e quella vescovile, l'unione dell'opera scientifica e quella pastorale, s'iscrive nell'illustre cerchio delle grandi personalità provenienti dalla famosa diocesi di Włocławek. 